\title{
A TALE OF TWO COLLAPSES: ENVIRONMENTAL VARIABILITY AND CULTURAL DISRUPTION IN THE MAYA LOWLANDS
}

\author{
HISTORIA DE DOS COLAPSOS: VARIABILIDAD AMBIENTAL \\ E INTERRUPCIÓN CULTURAL EN LAS TIERRAS BAJAS MAYAS
}

\author{
Nicholas P. Dunning ${ }^{a}$, Timothy Beach ${ }^{b}$, Liwy Grasiozo Sierra ${ }^{c}$, John G. Jones ${ }^{d}$, David L. Lentz ${ }^{e}$, \\ Sheryl Luzzadder-Beach ${ }^{f}$ Vernon L. Scarborough ${ }^{g}$, Michael P. Smyth ${ }^{h}$
}

\begin{abstract}
An expanding array of data is becoming available on past climate changes affecting the Maya Lowlands region. We examine the strengths and weaknesses of these data sets, both in terms of identifying general trends and specific events. We then use these data to develop a model based on adaptive cycles that addresses both environmental and cultural changes that occurred in the Terminal Preclassic and the Terminal Classic periods in several areas of the Maya Lowlands. In particular, we compare the variable experiences and trajectories of several ancient communities located in the elevated interior region with others situated on lower elevation coastal plains. In general, communities in lower elevation areas proved more resilient to environmental and cultural perturbations than those in the higher elevation interior.
\end{abstract}

Key words: maya lowlands, maya archaeology, paleoclimate.

Un expansivo ordenamiento de la información sobre los pasados cambios climáticos que afectaron a la región de las tierras bajas mayas se está haciendo disponible. Examinamos las fortalezas y debilidades sobre estos conjuntos de datos, tanto para identificar corrientes generales como eventos específicos. Posteriormente utilizamos esta información para desarrollar un modelo basado en ciclos adaptativos que tratan de cambios ambientales y culturales que ocurrieron durante los períodos Preclásico Terminal y Clásico Terminal en algunas áreas de las tierras bajas mayas. En particular, comparamos las experiencias y trayectorias variables de algunas comunidades antiguas localizadas en la región elevada del interior con otras situadas en elevaciones más bajas de las planicies costeras. En general, las comunidades en las áreas de elevaciones de menor altura probaron tener mayor habilidad de recuperación y adaptación a las perturbaciones ambientales y culturales que aquellas situadas en lugares con mayor altura del interior.

Palabras claves: tierras bajas mayas, arqueología maya, paleoclima.

\section{Introduction: Lowland Maya Civilization in Environmental Context}

Ancient Maya civilization has grown in the popular imagination since the $19^{\text {th }}$ century, often filled with images of crumpling temples covered by tropical forest, and produced numerous theories about the fate of Maya civilization. More recently, the Classic Maya "collapse" has been used, along with other examples from the ancient world, as a warning for modern civilization (e.g. Diamond 2005). For nearly a century, scholars have debated the role that climate or environmental change may have played in the course of Maya civilization (e.g. Huntington 1917). These debates have progressed from highly speculative to increasingly sophisticated as the number of paleoenvironmental proxies being analyzed had grown, the precision of these analyses has increased, and Maya archaeology became increasingly scientific. Since the early 1990s, evidence has mounted linking climate change, especially drought, to the Classic collapse as well as earlier and later downturns in the course of Maya civilization. Each proxy data set has its own strengths and weakness for identifying either general trends or specific events within the paleoenvironmental

a University of Cincinnati, Department of Geography, Estados Unidos. Correo electrónico: nicholas.dunning@uc.edu

b Georgetown University, Science, Technology, and International Affairs, Estados Unidos. Correo electrónico: beachtp@ gmail.com

c Museo Miraflores, Guatemala. Correo electrónico: liwygrazioso@ hotmail.com

d Archaeological Consulting Services, LTD, Arizona, Estados Unidos. Correo electrónico: pollendude@ hotmail.com

e University of Cincinnati, Department of Biological Sciences, Estados Unidos. Correo electrónico: david.lentz@uc.edu

f George Mason University, Department of Geography and Geoinformation Science, Estados Unidos. Correo electrónico: sluzzadderbeac@gmail.com

g University of Cincinnati, Department of Anthropology, Estados Unidos. Correo electrónico: vernon.scarborough@uc.edu

h University at Buffalo, Foundation for Americas Research, Inc. Estados Unidos. Correo electrónico: mpsmyth@ netzero.com 
record. After briefly reviewing these data below, we propose a broad model of environmental change in the Maya Lowlands and examine how it intersects with trends in Maya civilization. Our study suggests that while Maya communities shared a set of common vulnerabilities to environmental hazards, communities in some regions were considerably more vulnerable, and others more resilient to changing environmental conditions.

Ancient lowland Maya civilization spanned a period from about $1000 \mathrm{BC}$ to $1500 \mathrm{AD}$. Over the course of millennia, Maya civilization experienced several periods of growth and decline, often with highly different trajectories in various regions (Marcus 1993; Dunning and Beach 2010). The Maya Lowlands region comprises the carbonate Yucatan Platform and contiguous areas of Mexico and Central America and includes a mosaic of habitats created by variation in precipitation, drainage, and edaphic patterns. At the heart of the region is an area ranging from 40 to $300 \mathrm{~m}$ in elevation and often delimited by geologic scarps that we have elsewhere named the Elevated Interior Region or EIR (Figure 1) (Dunning, Beach, LuzzadderBeach 2012). Drainage is largely internal, except along the southern periphery of the EIR where

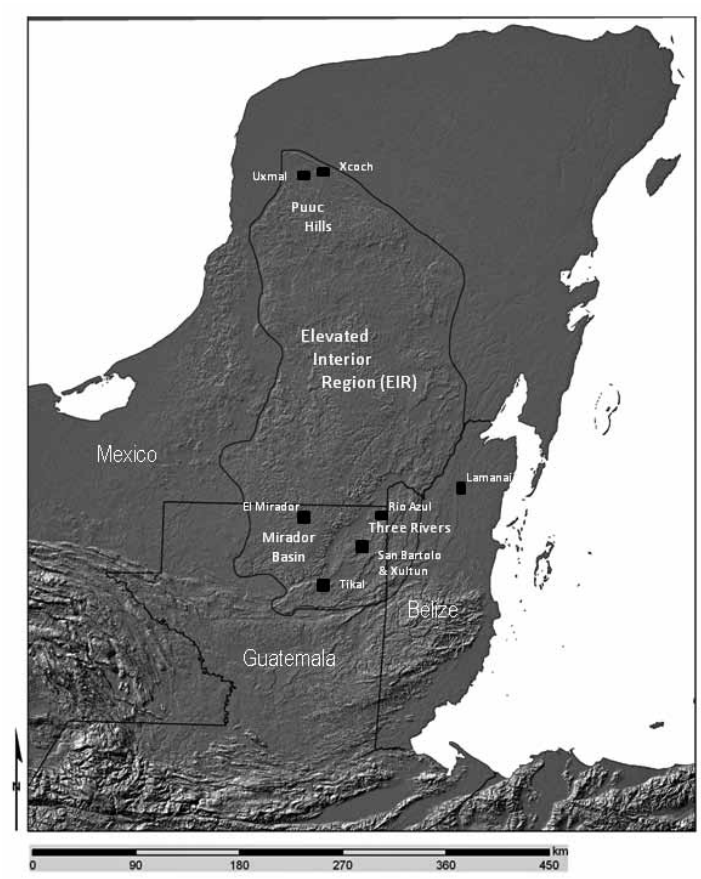

Figure 1. Map of the Maya Lowlands showing the location of the Elevated Interior Region (EIR) and sites mentioned in the text. rivers with large inputs of groundwater drain the margins of the interior. This region was the focus of spectacular periods of cultural development as expressed in monumental architecture both early and late in the course of Maya civilization including the Late Preclassic (BC 300 - AD 150) apogee in the Mirador Basin and the Late/Terminal Classic (AD 700-925) florescence in the Puuc Hills, regions that were also the scene of dramatic examples of cultural collapse and depopulation.

For the Maya Lowlands region, the key climate drivers are shifts in the Intertropical Convergence Zone (ITCZ) and subtropical high pressure masses that create a highly seasonal annual rainfall pattern, as well as a generally north to south rainfall gradient from about $1000 \mathrm{~mm}$ to nearly $3000 \mathrm{~mm}$. Changes in the pattern of ITCZ migration have also been linked to longer term climate changes and drought cycles (Haug et al. 2001). The size, Failure of the ITCZ to effectively push northward is strongly linked to periods of increased aridity that at times plague the Maya Lowlands.

Soils across the Maya Lowlands typically range from skeletal to shallow on elevated surfaces to deeper, more hydromorphic in depressions. Parent materials for the soils include airborne volcanic ejecta and eolian dusts as well as residual calcite derived from weathering limestone. The distribution of natural vegetation follows regional patterns of precipitation, drainage, and soils. From beach ridges and estuarine wetlands and savannas of the northern coasts, vegetation grades into low, tropical deciduous forest in the northern EIR. The forest increases in height following increasing precipitation southward becoming tropical moist forest in the southern EIR. These forests were well adapted to seasonal moisture deficits and periodic hurricane blow downs. Longer term climate cycles induced changes in the relative openness of the forest canopy, but over the past three millennia, the extent of forest cover has mostly co-varied with human population numbers. Embedded within the southern forest are numerous wetlands, ranging from seasonal swamp forests in karst depressions (bajos) within the EIR to perennial wetlands in adjacent lower areas that receive spring discharge and stream flow.

Though much of the lowand landscape was adaptable to the maize-based agricultural system of the ancient Maya, settlements in the region faced considerable vulnerabilities particularly as population density increased. These vulnerabilities 
included natural hazards such as recurring droughts, periodic hurricanes, and lack of access to either perennial surface or groundwater in many interior areas, particularly in the EIR. Human-related vulnerabilities included a host of issues related to forest reduction, soil degradation, as well as particular characteristics of Maya sociopolitical systems. In the EIR, permanent human settlement was directly tied to the ability to capture and store rainwater. In a region with a 4-plus-month-long dry season with little precipitation, such storage was a significant challenge and the Maya developed systems ranging from large urban reservoirs to household tanks and cisterns to facilitate settlement (Dunning 1992; Scarborough and Gallopin 1991; Scarborough et al. 2012; Weiss-Krejc and Sabbas 2002). This lack of water would have left settlements in the EIR especially vulnerable to drought.

Traditional Maya agriculture is highly adapted to the seasonal rhythms of regional precipitation. As ancient populations increased additional adaptations were made in order to intensify production, initially reducing risk, but adding to longer term vulnerability. The Maya Lowlands also experienced drying trends on an apparent cycle on the scale of hundreds of years and linked to migrations in the ITCZ (Hodell et al. 2001; Haug et al. 2001, 2003). These shifts lead to episodic increases in the frequency and severity of drought. In most of the Maya Lowlands meteorological drought could quickly translate into agricultural drought because of the rainfall-dependent nature of cultivation, and in turn lead to socioeconomic perturbation if it severely curtailed food production. Some low-lying areas with spring-fed or riverine wetlands would have been less vulnerable because of higher soil moisture levels, but even these areas would have suffered if drought severity increased to the point of adversely lowering discharge rates (LuzzadderBeach, Beach, and Dunning 2012).

\section{Paleoclimate Proxies:}

The modern study of paleoclimate and ancient Maya civilization began with attempts to associate Mesoamerican with European trends (e.g. Gunn and Adams 1981), but the first, regional evidence came in the 1990s based on studies that retrodicted the discharge of the Rio Candelaria, Mexico with models of global insolation, atmospheric patterns, and volcanic emissions that showed higher rainfall in the Classic period and dryer conditions in the Terminal Classic (Gunn, Folan, and Robichaux 1994). These studies have recently been expanded to correlate with sediments recovered in the Laguna de Terminos where the Candelaria discharges (Gunn et al. 2012).

Lake core studies at Laguna Chichancanab and Punta Laguna in the northern lowlands in the 1990s indicated climate change in the Yucatan based on the relative abundance of sulfur (S) to calcite $\left(\mathrm{CaCO}_{3}\right)$ in sediments and oxygen isotope ratios $\left(\delta^{18} \mathrm{O}\right)$ in benthic shells (Hodell, Brenner, and Curtis 2000, 2005; Hodell, Curtis, and Brenner 1995; Hodell et al. 2001). The Chichancanab study revealed two sharp peaks in sulfur in the Late Preclassic and Late Classic, that the $\delta^{18} \mathrm{O}$ ratios partly parallel in the Preclassic and fully parallel in the Late Classic. These two peaks are indicative of drought, and are followed by a return to Preclassic levels of $\delta^{18} \mathrm{O}$ and $\mathrm{S}$ and $\mathrm{CaCO}_{3}$ ratios (Brenner et al. 2002). The Punta Laguna study indicates peak drought in the Terminal Classic as well (Curtis, Hodell, and Brenner 1996). These studies were initially questioned by some because of poor temporal resolution and doubts about their applicability to the Maya Lowlands as a whole.

Laminated, marine sediments from the Cariaco Basin off the Venezuelan coast some $2000 \mathrm{~km}$ southeast of the Maya Lowlands, provide another proxy evidence of variations in sedimentary titanium and iron from terrestrial erosion and runoff (Haug et al. 2001, 2003). These sediments indicate high variability from c. 3800 to c. $2000 \mathrm{BP}(01850 \mathrm{BC}$ to $50 \mathrm{AD}$ ), and stability from 2000 to $1300 \mathrm{BP}(50$ $\mathrm{BC}$ to $650 \mathrm{AD}$ ), low quantities from 1300 to 1000 $\mathrm{BP}$ (650-950 AD), and the lowest quantities during the Little Ice Age (500-200 BP; 1450-1760 AD). The authors argue that low Ti concentrations, reflecting reduced precipitation, correspond to c. 760,810 , 860 , and $910 \mathrm{AD}$, and the Maya Late and Terminal Classic Periods. Although these data provided much finer temporal resolution, critics wondered about their applicability to the Maya Lowlands.

Though nearly absent within the EIR, lakes are common in structural troughs along its margins. To date, however, lacustrine evidence from the heart of southern lowlands in the Petén of Guatemala has been equivocal because although $\delta^{18} \mathrm{O}$ evidence indicates greater evaporation in the Terminal Classic, it may indicate either hotter and dryer conditions or simply reforestation (Yaeger and Hodell 2008; Rosenmeir 
et al. 2002). Sedimentation rates within these lakes can be linked to longer-term climate changes and associated changes in vegetative cover within the Pleistocene (Mueller et al. 2010). Within the EIR, numerous small bodies of water (aguadas) are typically the combined product of karst solution and Maya engineering. Coring and excavations in several aguadas has revealed evidence both for drought in the Late Preclassic and the Terminal Classic as well as ancient Maya management strategies (Akpinar-Ferrand et al. 2012). Lakes as well as aguadas have also proven to be valuable repositories of ancient pollen.

Findings from speleothem studies in Belize and Yucatan provides further evidence of ancient droughts. From cave laminae in southern Belize, Webster et al. (2007) used color, luminescence, $\delta^{13} \mathrm{C}$, and $\delta^{18} \mathrm{O}$ as precipitation proxies to suggest Preclassic climate flux from drought to pluvial, Late Preclassic (5 BC and $141 \mathrm{AD}$ ) severe droughts, Classic Period wetter conditions sandwiching a drought in the Middle Classic (517 AD), and Late through Post Classic (780, 910, 1074, and 1139 AD) severe droughts. In northern Yucatan paleoprecipitation records gathered from a speleothem found in Tecoh Cave indicate that the northern lowlands experienced a similar chronological pattern of decreased rainfall including a series of eight multiyear droughts, 3 to 18 years in length, between 806 and 935 AD (Medina-Elizade at al. 2010). These studies show the high potential of spelethems as paleoclimate proxies in the karst Maya Lowlands, including the possibility of providing measures of annual precipitation. However, it needs to be borne in mind that these records can be severely affected by localized land use changes and will be most meaningful when multiple records can be obtained for the region. Other attempts to analyze speleothems are ongoing, but have been limited by dating problems associated with low Th levels and disruptions found in individual speleothem formation processes.

Wetlands within the Maya Lowlands also preserve a number of paleoenvironmental proxies (e.g. Beach et al. 2009; Luzzadder-Beach, Beach, and Dunning 2012). Sea-level changes are closely linked to longer-cycle climate change. Because of low elevation, low gradient and rate of fluvial contributions, and proximity to the ocean, the wetlands of the coastal lowlands are extremely sensitive to changes in sea-level and even small changes can induce dramatic changes in water quality and associated ecosystem responses. Sea-level rise also induced aggradation through associated fluvial systems, often compounded by land use changes. In many areas, the ancient Maya extensively manipulated the hydrology of coastal lowland wetlands attempting to maintain suitable conditions for cultivation. Many wetlands have suitable microenvironments preserving pollen and other paleoclimate proxy matierials.

Pollen morphs can give evidence of vegetation and climatic change, but they often produce evidence that can have equifinalities and multifinalities because factors for ecological assemblages are complicated and pollen types are far from equally represented in deposition. While larger lake basins have been most studied for pollen in the Maya Lowlands (e.g., Mueller et al. 2010), pollen sampling from the sediments in these bodies of water are likely to over-represent prolific wind-pollinated species and under-represent insect-pollinated types. Given that many economically valuable trees favored by the Maya are insect-pollinated, the anthropogenic transformation of the lowland forest into a more managed version may be "misrepresented" in the sedimentary pollen record as a decline in forest cover (Ford and Nigh 2013). In the EIR, where lakes are essentially absent, pollen has been successfully recovered from some aguadas. These smaller bodies catch a more localized pollen rain and insectpollinated economic trees are better represented, as well as are many cultigens (e.g. Akpinar et al. 2012). However, since the Maya often dredged these ponds to increase their water-holding capacity, the ancient pollen record is often truncated.

Given the limitations of any individual proxy to effectively reconstruct paleoenvironmental conditions, scholars are best advised to combine multiple proxies, either through using multiple proxies from the same environment or by using a comparative analysis of proxies from several environments (e.g., Medina-Elizade and Rohling 2012). Such combinations allow for the development of more realistic models. Multiple overlapping lines of evidence indicate dry conditions triangulated the Maya Lowlands during the Late Preclassic, again in the Terminal Classic, and possibly other times during the course of Maya civilization. These periods coincided with significant population losses in many areas as well as significant transformations in Maya society. 


\section{Climate Change, Anthropogenic Environmental Change, and the Ancient Maya}

Forest cover has waxed and waned across the Maya Lowlands for millennia reflecting both longer-term climate cycles as well as human activity (Dunning and Beach 2010). While intact the forest provided the Maya with many resources. The ancient Maya intentionally left standing patches of managed forest as well as individual valuable trees within fields (Ford and Nigh 2013; Lentz and Hockaday 2009). However, paleoecological data from throughout the Maya Lowlands document a strong correlation between rising human populations and forest decline as timber was consumed and agricultural fields opened.

Forest removal produced many inter-related, and often negative, effects on the regional environment. Declining forest cover likely translated into reduced local transpiration and precipitation, potentially significantly increasing drought persistence and intensity (Oglesby et al. 2010) as well as reducing soil moisture levels. Removal of forest cover also left sloping land vulnerable to soil loss via erosion (Dunning and Beach 2000; Anselmetti et al. 2007). Associated sedimentation within karst depressions and stream channels had profound effects on local hydrology, reducing recharge and inducing eutrophication of shallow water bodies, effecting long-term transformation of perennial moist areas into seasonal wetlands (Castañeda Salguero 1995; Dunning et al. 2002). Reductions in tree canopy would also reduce the capture of airborne volcanic ash (a principal component of the inorganic fraction of regional soils: Tankersley et al. 2011), soot, as well other forms of airborne Phosphorus, a nutrient already in critically low supply in most Maya Lowlands soils (Lawrence et al. 2009; Das et al. 2011). Reductions in forest fallowing would also likely decrease Nitrogen levels by reducing inputs from leguminous Leucaena species, which compose a significant portion of regional forests (Flores and Carvajal 1994). Declining soil fertility would also increase vulnerability to field invasion by weedy species, most notably bracken fern (Pérez-Salicrup 2004). In sum, while the high base status soils and tropical climate of the Maya Lowlands were favorable for cultivating maize and supporting high population densities, the incremental reduction of forest for construction material, fuel, and farm land associated with population growth and urbanization would have created a downward spiral towards unsustainable conditions within the region, especially when coupled with other environmental and cultural risk factors.

Archaeologists have pointed out that the Classic Maya sociopolitical system was itself prone to collapse (Demarest, Rice, and Rice 2004). As noted by McAnany and Gallareta Negrón (2010: 157) “...divine kingship is a double-edge sword: it carries great privilege and unlimited power but also demands that a ruler deliver munificence to their people as would a god. A string of military defeats or seasonal drought can do much to damage the credibility of a divine ruler..." The sociopolitical system to some degree depended on expansionistic growth that funneled wealth into the ruling elite. Warfare and a tribute-based status system created pressure for rulers to agglomerate population. Data from both pre-Hispanic and Colonial times indicate that during periods in which the mobility of populations was restricted either by force or because that landscape was simply "full" were likely to witness more dramatic demographic decline and political economic failure associated with perturbations such as drought or warfare (Inomata 2004; Mendoza et al. 2006). In short, the rigidity of the sociopolitical system provided few options for change that severely limited cultural resilience.

Many scholars have strongly objected to "drought causes collapse" scenarios as reductionist and deterministic (e.g. McAnany and Gallareta Negrón 2010; Turner 2010; Aimers and Iannone 2013). These contrasting views stem in part from differing views of the nature of "collapse" and the sheer complexity of this phenomenon as it played out across time and space. Critics of the recent deterministic models of collapse in the Maya Lowlands view the Terminal Classic and earlier "Terminal Preclassic" as periods of profound transformation and transition in Maya society and not necessarily of "collapse" (cf. Demarest, Rice, and Rice 2004). There are notably few examples of rapid, apocalyptic depopulations in Maya history, except perhaps at a few individual sites. In contrast, the process of multi-site and regional abandonment in the Terminal Classic played out over at least 125 years (the Terminal Preclassic decline is much less understood). Nevertheless, the changes that occurred in Maya society during these periods were profound and enduring, including long-term population loss over sizable areas. 
As discussed above, all paleoenvironmental proxies offer incomplete windows on the past. Similarly, archaeological data present partial patterns at best. Modeling past human-environments requires these frayed thread be woven back together with as much precision as possible. Nevertheless, the true complexity of the human-environment system can only be approximated. Our brief review here of the complex and varied course of Maya civilization focuses on the northern and southern extremes of the EIR and two periods of demographic decline and cultural transition: the Terminal Preclassic (ca. 100-250 AD) and Terminal Classic (ca. 750950 AD). For most areas, both archaeological and paleoenvironmental data are more abundant for the later period than the earlier, in part because later processes and patterns often obscured earlier ones, but also because scientific research has only more recently begun to adequately address earlier periods.

The east-central Yucatan Peninsula includes the Mirador Basin at the heart of the landmass, as well as the fractured and block-faulted eastern edge of the Peten Karst Plateau (also known as the Three Rivers region), and the coastal plains of northern Belize (Dunning et al. 2002). This area includes abrupt gradients formed by escarpments as one moves westward from the coastal lowlands into the interior. Large and small wetlands (bajos) cover over $45 \%$ of the land surface in the EIR here and many of the largest and earliest-settled Maya communities were located on the margins of these depressions, some of which once held shallow lakes or perennial wetlands. Around $50 \mathrm{AD}, \mathrm{El}$ Mirador alone boasted over 40 triadic pyramid groups including some of the largest monuments ever constructed in Mesoamerica. By $150 \mathrm{AD}, \mathrm{El}$ Mirador and most larger sites within the Mirador Basin lay desolate and most would see only scant reoccupation several hundred years later. As noted earlier, multiple paleoenvironmental proxies indicate that the $2^{\text {nd }}$ century $\mathrm{AD}$ was a period with significantly increased drought frequency and severity across the Maya Lowlands. Sediments with several bajos in the Mirador Basin and a nearby lake indicate that this area experienced widespread deforestation and soil erosion. These changes were associated with land clearing and quarrying, in significant part to generate plaster for the huge pyramids, for centuries preceding regional abandonment suggesting that anthropogenic environmental degradation was at least as important as drought in bringing about the demise of El Mirador and its allied centers (Wahl et al. 2007).

In the Three Rivers region east of the Mirador Basin, site survival or abandonment was more erratic (Dunning, Wahl et al. 2012). For example, at San Bartolo and Xultun, sites only $8 \mathrm{~km}$ apart and in the same physiographic setting, the Maya abandoned San Bartolo around $150 \mathrm{AD}$ while Xultun grew into an important Classic center (Garrison and Dunning 2009). Significantly, Xultun invested in a large scale reservoir system whereas San Bartolo did not and would not be reoccupied again until around $700 \mathrm{AD}$ (Akpinar-Ferrand et al. 2012). In regional centers that survived through the Terminal Preclassic social upheaval is nevertheless evident, with many Preclassic building complexes ritually terminated and new ones initiated, many associated with a new system of dynastic kingship. For example, at Río Azul, a Late Preclassic temple complex was ritually entombed and a new complex initiated elsewhere at the site (Valdez, Grazioso, and Buttles 2001). Communities that developed into Classic urban centers in the region also typically exhibit investment in sizeable reservoirs, a phenomenon likely related to the identification of new dynastic rulers with water control (Lucero 2002). Tikal provides an example of a highly successful Classic period city and polity in the EIR. The development of reservoirs and water management systems tracks closely with the growth of the urban center (Scarborough et al. 2012). Over time, the reservoir system became increasingly sophisticated, with specialized tanks keyed to potable or agricultural purposes. For example, Corriental Reservoir included sluices to capture or exclude water as needed and sand filters to enhance potability (Figure 2). Overall, the Early and Late Classic periods witnessed overall population growth with widespread development of urban centers within the Three Rivers region (Garrison and Dunning 2009) and throughout much of the EIR. This development was hardly tranquil, because violent competition between rival polities and dynasties increased through the period (Martin and Grube 2010). While this competition was in part driven by the nature of the Maya political system, it also undoubtedly involved the need to control land and labor - a process that likely accelerated as population increased and resources became scarcer (Dunning and Beach 2010).

Paleoenvironmental data indicate that deforestation escalated in the Late Classic as population increased 


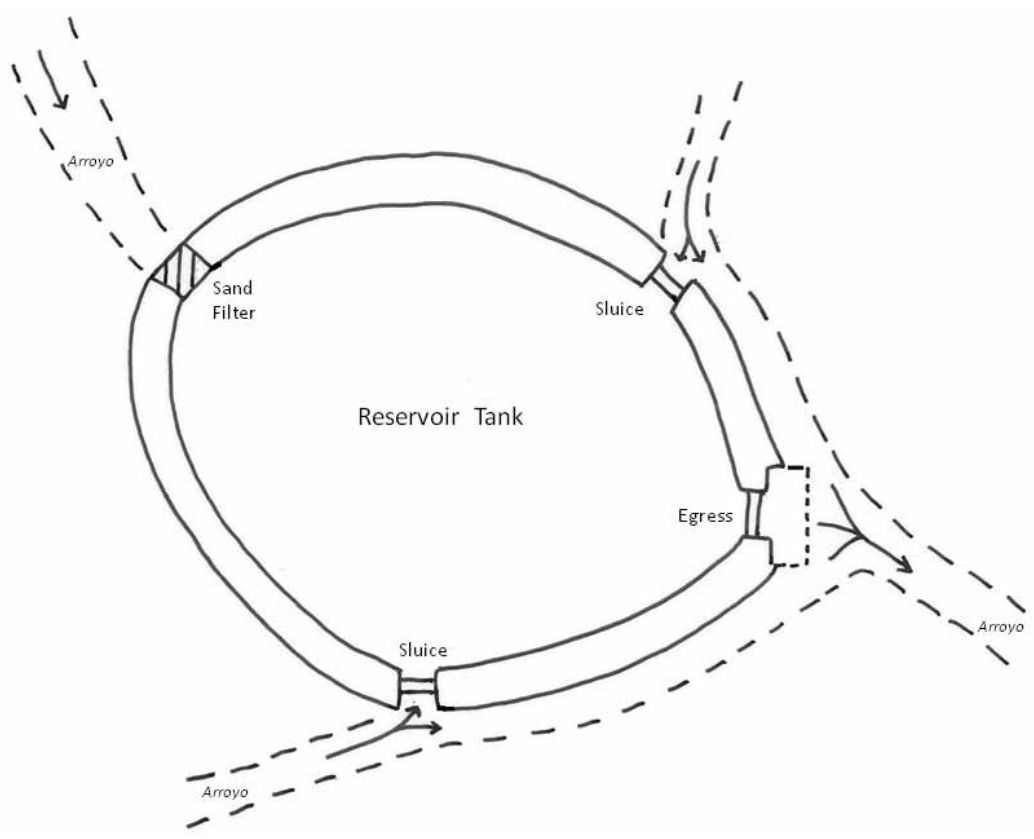

Figure 2. Idealized plan of Corriental Reservoir, Tikal, Peten, Guatemala.

and demands for timber and croplands rose at Tikal and elsewhere (Beach et al. 2008; Lentz and Hockaday 2009). In some areas, terracing was used to arrest soil erosion, in others it was not (Beach et al. 2006; Dunning and Beach 2010). Beginning around 760 $\mathrm{AD}$, some paleoenvironmental data indicate that the first in a series of severe droughts beset the Maya Lowlands . Around this same time, abandonment of Late Classic sites begins, though in areas not obviously vulnerable to drought such as in the Río de la Pasión and Usumacinta drainages, among the best watered parts of the Maya Lowlands. However, these areas show evidence for little wetland agriculture and marginal soil resources; thus, it is possible that "agricultural drought" could have disrupted communities dependent on rain-fed cultivation. The marginal nature of land may also have meant that competition between rival dynastic centers over goods and labor became acute earlier than in other regions. Such competition was manifest in extraordinarily violent conflict including the sacking and burning of towns until the region degenerated into a landscape of fear and desertion (O'Mansky and Dunning 2004). This pattern of abandonment was sometimes sudden, but sometimes a lingering death took hold such as in the Three Rivers region and other parts of the southern and central EIR over the course of the $9^{\text {th }}$ century; and by $900 \mathrm{AD}$ much of the region was effectively depopulated (Quintana and Wurster 2001; Palka 2003). Paleoenvironmental data indicate that the regional forest returned to pre-Maya levels within 100-200 years following abandonment, yet, with the exception of a few areas such as the Central Peten Lakes lying to the south of the EIR proper, people did not (Mueller et al. 2010).

The Belizean coastal plain borders the eastern edge of the EIR, and connects the Maya Lowlands with the Caribbean Sea. Elevation in the coastal plain runs from sea level to about $10 \mathrm{~m}$ AMSL. Water is available from rivers tracing a series of $\mathrm{S}-\mathrm{N}$ running normal faults and grabens in northern Belize and also from sinkholes and wells accessing near surface groundwater. Some ancient Maya settlements occupied the coastal fringe and the offshore islands and may have functioned as trade ports with inland cities (Graham and Pendergast 1989). A number of coastal sites such as Cerros were abandoned in the Terminal Preclassic, perhaps as the result of sea-level rise or the collapse of early trade routes (Reese-Taylor and Walker 2002)), while other sites show considerable longevity including continuous occupation from the Classic into the Postclassic (Masson 2000). Several significant Maya sites occupied the wetlands and river valleys 
of the mainland coastal plain, including Lamanai (with occupation from $1500 \mathrm{BC}$ to $1500 \mathrm{AD}$ : Graham 2001). The hallmark environmental change experienced by many of these sites was either the direct or secondary influence of rising sea levels, which eventually inundated some coastal sites, or engendered major land transformations to adapt to rising groundwater tables, including wetland agriculture, in the evolving landscape (LuzzadderBeach, Beach, and Dunning 2012; Turner and Harrison 1983; Pohl and Bloom 1996).

The Puuc Hills lie at the northernmost end of the EIR. On the low-lying bordering plains to the north and west of the Puuc groundwater was accessible via sinkholes (cenotes) and wells. In contrast, in the uplifted Puuc groundwater is obtainable only in a handful of deep caves posing a barrier to year-round settlement. However, Puuc soils are renowned for their high quality making permanent settlement in the region desirable. Until recently, ancient settlement of the Puuc was believed to have been largely limited to the period between 700-950 AD when the region experienced explosive growth and architectural florescence. Research over the past 20 years, however, has revealed sizeable settlements dating to "Middle Classic" (400-700 AD) and Preclassic (BC 800-150 AD) times (Rivera Dorado 1996; Smyth 1998; Smyth et al. 2013). At the site of Xcoch, a large Preclassic populace constructed huge monumental architecture and elaborate reservoir system (Dunning, Weaver et al. 2013). The largest reservoir at the site, La Gondola, had a capacity of about 79,200,000 liters (Figure 3). However, despite that investment Xcoch was apparently abandoned around $150 \mathrm{AD}$ before being re-occupied ca. $400 \mathrm{AD}$, a process that included refurbishment of the reservoir system.

On the adjacent low-lying plains of Yucatan, where groundwater is often easily accessible but soils often poor, the Terminal Preclassic is also not well understood (Glover and Stanton 2010). While there was certainly a pattern of widespread site abandonment, the region as whole remained largely populated. Like other parts of the Maya Lowlands, social upheaval and reorganization are evident in dramatic shifts in material culture and settlement patterns. It is noteworthy that rainfall amounts across the northern lowlands are significantly lower than those in the south and inter-annual variation is somewhat higher. Maya farmers in the north have by necessity adapted to a less dependable precipitation regime than their southern neighbors perhaps making the regions communities less vulnerable during periods of increased aridity.

In the $5^{\text {th }}$ through $7^{\text {th }}$ centuries $\mathrm{AD}$ reoccupation of the Puuc Hills proceeded at a modest pace, then

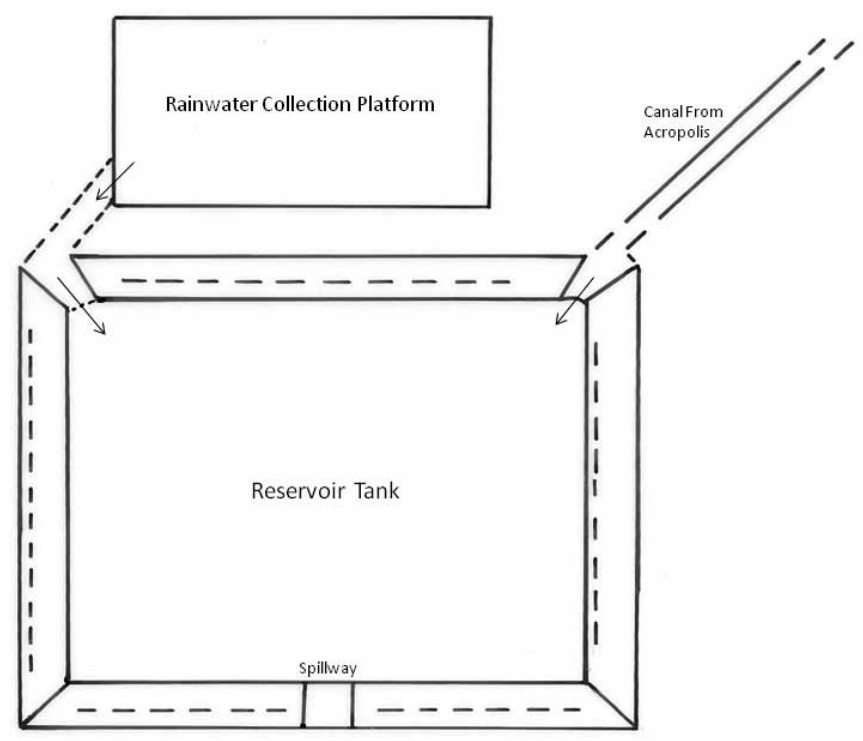

Figure 3. Idealized plan of Aguada La Gondola, Xcoch, Yucatan, Mexico. Dashed lines along the interior of the reservoir tank represent stepped benches allowing access to descending water levels. 
witnessed explosive growth of regional population in the $8^{\text {th }}$ and early $9^{\text {th }}$ centuries with established centers expanding and new towns being founded (Dunning 1992). The high productivity of Puuc soils likely underwrote this dramatic growth, but analysis of Puuc soils and cropping systems indicates that maximal yields would likely have been sustainable for only about 75 years (and no more than 100), followed by significant declines in fertility and yields (Andrews 2004). This duration is coincident with the peak occupation of most Terminal Classic Puuc centers (ca. 770-870 AD). After around $870 \mathrm{AD}$, many centers declined, but Uxmal grew dramatically and produced some of the most spectacular architecture in the Maya world (Kowalski and Dunning 1999). Iconography and inscriptions at Uxmal indicate that its growth may have been accomplished by preying on weakened neighbors (Carmean, Dunning, and Kowalski 2004). However, sometime after $910 \mathrm{AD}$, Uxmal too was largely abandoned apparently under duress. As noted above, paleoprecipitation records gathered from speleothems indicate that the northern lowlands and Puuc experienced a similar chronological pattern of decreased rainfall (Medina Elizade et al. 2010) including eight apparent droughts between 806 and $935 \mathrm{AD}$. These droughts spanned the time of both maximal population growth and decline in the Puuc. The concentration of population in the Puuc during the Terminal Classic was accomplished through the use of both urban reservoirs and tens of thousands of household cisterns. This combination of water capture and storage systems may have allowed the Puuc Maya to withstand droughts better than in other parts of the EIR (Dunning et al. 2012). However, rising population, declining forest cover, declining soil fertility, and reduced soil moisture likely proved lethal in the $10^{\text {th }}$ century. Small numbers of people hung on in some Puuc centers into the $11^{\text {th }}$ century or later, but the region was never effectively repopulated in pre-Hispanic times.

Like the Terminal Preclassic, the Terminal Classic period on the northern plains of Yucatan saw regional population decline and abandonment of some sites, but no widespread regional depopulation. One clear example of how no one prime mover can explain the Maya abandonment is the sprawling site of Chunchucmil, lying just $30 \mathrm{~km}$ northwest of the Puuc. This site contrasts with the Puuc sites in that it diminished far before any climatic deterioration in the early part of the Late Classic (ca. $7^{\text {th }}$ century
CE), but unlike the Puuc had accessible and good water supplies but thin soils (Dahlin et al. 2005). Instead, reorganization is again evident culminating in new settlement patterns and sociopolitical forms (Andrews et al. 2003).

\section{Discussion}

Complex systems often contain amplifying elements. In the case of lowland Maya civilization, periods of increased aridity amplified vulnerabilities in the environment, especially in the EIR, such as karst hydrology and limitations in the resilience of the regional forest and soilscape. When increased aridity coincided with periods of population growth, and growth-dependent political institutions, multiple amplifiers went into effect (Turner and Sabloff 2012). Such complex coupled systems involve multiple points of intersection, interaction, and feedback that can have catastrophic results when elements become increasingly unbalanced (Berkes and Folke 1998). Applying this to the vulnerabilities and resilient capacities of ancient Maya Lowland communities, it is clear that the elevated interior portions were significantly more susceptible to collapse and faced greater obstacles for effective reorganization than the surrounding lower-lying areas with perennial water sources. However, even many communities in these supposedly more resilient areas eventually succumbed to abandonment (LuzzadderBeach, Beach, and Dunning 2012). Ancient Maya communities on the coastal plains had more options for change and resilient capacity than did those in the EIR. Most importantly plains communities had more dependable access to drinking water. In some southern coastal plain areas wetland agriculture also offered some security against agricultural drought, though the hydrology of the wetlands was dynamic and challenging. Plains communities were also more closely and easily integrated into river and maritime trade networks, an advantage that was manifest in the growth of maritime trade in the Postclassic (Graham 2001). While social and political institutions collapsed on the plains, population declines were typically less severe.

System rigidity posed problems for communities in all regions, especially as population levels increased and competition between rival polities escalated. As many have noted, the ruler-centric Maya political system was poorly suited to withstand environmental and economic perturbations in part 
because failures condemned the legitimacy of kings and the political system itself. To a significant degree the Maya collapses were first and foremost elite and urban phenomena, with the repercussions on rural populations less clear, but in many cases more muted and delayed (Robin 2001). In some regions smaller centers survived longer than in others; in some centers the institution of divine kingship disappeared, but population remained for many years and revamped Postclassic communities emerged (Lucero 2002; Sabloff 2007).

Scrutiny of the Terminal Preclassic and Terminal Classic collapses reveals few apocalyptic events and no prime movers. Instead these phenomena were generally complex, multi-generational, and asynchronous: decline typically followed from many years of growth, but growth that contained the seeds of future failure. Population growth and forest removal went hand in hand with political expansions but created escalating risk and vulnerability. The Maya Lowlands and Maya society also contained numerous potential "triggers" to initiate system collapse or reorganization. These triggers included droughts, hurricanes (Dunning and Houston 2011), and volcanic eruptions (capable of choking or fouling reservoirs in the EIR: Tankersley et al 2011; Scarborough et al. 2012), all of which could generate system-stressing crop failures and population movements (Dunning, Beach, and Luzzadder-Beach 2012). The political system itself also provided triggers in the form of warfare spawned by inter-polity competition among prestige-obsessed dynasts. Comparable to collapses documented for other cultures these phenomena were multi-causal and characterized by cascading feedbacks (Butzer and Endfield 2012).

Current discussions of collapse in the Maya Lowlands raise the question of why some regions, notably those in the EIR, were slow to be effectively reoccupied or were not reoccupied at all after collapse (e.g., Turner 2010). Hydrologic problems lie at the heart of this issue. Reoccupation of the EIR by sizeable populations required a system to capture and store rain water. In the Preclassic and Classsic periods, such systems developed in situ within the EIR as an integral part of Maya society. After the collapse of that society in the Terminal Preclassic and again in the Terminal Classic, these hydraulic systems were abandoned and reoccupation by large numbers of people and urbanization required labor-intensive revitalization or replacement. These efforts were less necessary on the coastal plains and widespread continuity of occupation is more evident even when political and economic structures failed or were overhauled. In Classic Maya polities failure implicated both gods and rulers and their former territories became places of ill fortune and the reoccupation of abandoned places called for reorganization of a most profound kind.

\section{References Cited}

Aimers J., and G. Ianone

2013 The dynamics of ancient Maya developmental history. In The Great Maya Droughts in Cultural Context (G. Iannone editor) University of Colorado Press, Boulder. In press.

Akpinar-Ferrand, E.; N.P. Dunning; J.G. Jones and D.L. Lentz 2012 Use of aguadas as water sources at two southern Maya lowland sites. Ancient Mesoamerica 23: 85-102.

Andrews, A.P.; E.W. Andrews and F. Robles Castellanos

2003 The northern Maya collapse and its aftermath. Ancient Mesoamerica 14: 151-156.

Andrews, B.W.

2004 Sayil revisited: inferring Terminal Classic population size and dynamics in the west-central Yucatan Peninsula. Human Ecology 32: 593-613.

Anselmetti, F.S.; D.A. Hodell; D. Aritegui; M. Brenner and

M. Rosenmeier

2007 Quantification of soil erosion rates related to ancient Maya deforestation. Geology 35: 915-918.

Beach, T.; N. Dunning; S. Luzzadder-Beach; J. Lohse and D. Cook 2006 Ancient Maya impacts on soils and soil erosion. Catena 66: 166-178.
Beach, T.; S. Luzzadder-Beach; N.P. Dunning and D. Cook 2008 Human and natural impacts on fluvial and karst systems in the Maya lowlands. Geomorphology 101: 301-331.

Beach, T.; S. Luzzadder-Beach; N.P. Dunning; J.G. Jones; J. Lohse;

T. Guderjan; S. Bosarth; S. Millspaugh and T. Bhattacharya 2009 A review of human and natural changes in Maya Lowlands wetlands over the Holocene. Quaternary Science Reviews 28: 1710-1724.

Berkes, F. and C. Folke

1998 Linking social and ecological systems for sustainability. In Linking Social and Ecological Systems (F. Berkes and C. Folke editors) Cambridge University Press, Cambridge UK, pages 1-25.

Brenner, M.; M. F. Rosenmeier; D. A. Hodell and J. Curtis. 2002 Paleolimnology of the Maya Lowlands. Ancient Mesoamerica 13: 41-157.

Butzer, K.W. and G. Endfield

2012 Critical perspectives on historical collapse. Proceedings of the National Academy of Science 109: 3612-3618.

Carmean, K.; N.P. Dunning and J.K. Kowalski

2004 in High times in the hill country: the Terminal Classic in the Puuc region. In The Terminal Classic in the Maya 
Lowlands: Collapse,Transition, and Transformation (A. Demarest, P.Rice, and D. Rice editors) University of Colorado Press, Boulder, pages 424-449.

Castañeda Salguero, C.

1995 Sistemas Lacustres de Guatemala: Recursos que Mueren. Editorial Universitaria, Universidad de San Carlos, Guatemala.

Curtis, J.H.; D.A. Hodell and M. Brenner

1996 Climate variability on the Yucatan Peninsula (Mexico) during the past 3500 years, and implications for Maya cultural evolution. Quaternary Research 46: 37-47.

Dahlin, B.H.; T. Beach; S. Luzzadder-Beach

2005 Reconstructing agricultural self-sufficiency at Chunchucmil, Yucatán, Mexico. Ancient Mesoamerica 16: 229-247.

Das, R.1 Lawrence D.1 D.D'odorico and M. Delonge 2011 Impact of land use change on atmospheric P inputs in a tropical dry forest. Journal of Geophysical Research 116, G01027, doi:10.1029/2010JG001403,2011

Demarest, A.A.

2004 After the maelstrom: collapse of the Classic Maya kingdoms and the Terminal Classic western Peten. In The Terminal Classic in the Maya Lowlands: Collapse, Transition, and Transformation (A. A. Demarest, P. M. Rice, and D. S. Rice editors), University of Colorado Press, Boulder, pages 102-124.

Demarest, A.A.; P.M. Rice and D.D. Rice

2004 The Terminal Classic in the Maya Lowlands: assessing collapses, terminations, and transformations. In The Terminal Classic in the Maya Lowlands: Collapse, Transition, and Transformation (A. Demarest, P. Rice, and D. Rice editors), University of Colorado Press, Boulder, pages 545-571.

Diamond, J.

2005 Collapse: How Societies Choose to Fail or Succeed. Penguin Books, New York.

Dunning, N.P.

1992 Lords of the Hills: Prehispanic Settlement in the Puuc Region, Yucatan, Mexico. Prehistory Press, Madison WI.

Dunning, N.P. and T. Beach

2000 Stability and instability in Pre-Hispanic Maya landscapes. In An Imperfect Balance: Landscape Transformations in the Precolumbian Americas (D. Lentz editor) Columbia University Press, New York, pages 179-202.

Dunning, N.P. and T. Beach

2010 Farms and Forests: Spatial and temporal perspectives on ancient Maya landscapes. In Landscapes and Societies (I. P. Martini and W. Chesworth editors), Springer, Berlin, pages 369-389.

Dunning, N.; T. Beach; P. Farrell and S. Luzzadder-beach 1998 Prehispanic agriculture and adaptive systems in the Maya Lowlands. Culture and Agriculture 20: 87-101.

Dunning, N.P.; T. Beach and S. Luzzadder-Beach 2012 Kax and kol: collapse and resilience in lowland Maya civilization. Proceedings of the National Academy of Sciences USA. 109: 3652-3657.

Dunning, N.P. and S. Houston

2011 Chan Ik: hurricanes as a disruptive force in the Maya Lowlands. In Ecology, Power, and Religion in Maya Landscapes (C. Isendahl and B.L. Persson editors), Verlag Anton Sauerwien, Berlin, pages 49-59.
Dunning, N.P.; S. Luzzadder-beach; T. Beach; J.G. Jones; V. Scarborugh and T.P. Culbert

2002 Arising from the bajos: the evolution of a Neotropical landscape and the rise of Maya civilization. Annals of the Association of American Geographers 92: 267-282.

Dunning, N.P.; D. Wahl; T. Beach; J.G. Jones; S. Luzzadder-

Beach and C. Mccormick

2013 The end of the beginning: environmental instability and the Terminal Classic collapse in the east-central Maya Lowlands. In The Great Maya Droughts in Cultural Context (G. Iannone editor) University of Colorado Press, Boulder, in press.

Dunning, N.; E. Weaver; M.P. Smyth; D. Ortegón Zapata

2013 Xcoch: home of ancient Maya rain gods and water managers. In The Archaeology of Yucatan: New Directions and Data (T. Stanton editor) BAR International Series, Oxford, in press.

Flores, J.S. and J.E. Carvajal

1994 Tipos de Vegetación de la Península de Yucatán. Etnoflora Yucatanese $\mathrm{N}^{\circ}$ 3. Universidad Autónoma de Yucatán, Mérida.

Ford, A. and R. Nigh

2013 Climate change in the Maya forest: resilience and adaptive management across millennia. In The Great Maya Droughts in Cultural Context (G. Iannone, editor) University of Colorado Press, Boulder.

Garrison, T.G. and N.P. Dunning

2009 Settlement, environment, and politics in the San Bartolo - Xultun territory, el Peten, Guatemala. Latin American Antiquity 20: 525-552.

Gill, R.B.

2000 The Great Maya Droughts. University of New Mexico Press, Albuquerque.

Glover, J.B. and T.W. Stanton

2010 Assessing the role of Preclassic traditions in the formation of Early Classic Yucatec cultures, Mexico. Journal of Field Archaeology 35: 58-77.

Graham, E.

2001 Collapse, conquest, and Maya survival at Lamanai, Belize. Archaeology International 4: 52-56.

Graham, E. and D.M. Pendergast

1989 Excavations at the Marco Gonzalez site, Ambergris Cay, Belize, 1986. Journal of Field Archaeology 16: 1-16.

Guderjan, T.; T. Beach; S. Luzzadder-Beach and S. Bosarth 2009 Understanding the causes of abandonment in the Maya Lowlands. Archaeological Review from Cambridge 24: 99-121.

Gunn, J.D. and R.E.W. Adams

1981 Climatic Change, Culture, and Civilization in North America. World Archaeology 13: 85-100.

Gunn, J.D.; J.E. Foss; W.J. Folan; M. del Rosario Domínguez Carrasco and B.B. Faustb

2002 Bajo sediments and the hydraulic system of Calakmul, Campeche, Mexico. Ancient Mesoamerica 13: 297-316.

Gunn, J.D.; W.J. Folan, J.W. Day and B.B. Faust

2012 Laguna de Términos/Río Candelaria core: conditions of sustainable urban agriculture in the interior of the Yucatan Peninsula. Estudios de Cultura Maya 36: 67-97.

Hansen, R.D.; S. Bosarth; J. Jacob; D. Wahl and T. Schreiner 2002 Climatic and environmental variability in the rise of Maya civilization: a preliminary perspective from the northern Peten. Ancient Mesoamerica 13: 273-297. 
Haug, G.H.; K.A. Hughen; L.C. Peterson; D.M. Sigman;

U. Röhl

2001 Southward migration of the Intertropical Convergence Zone through the Holocene. Science 293: 1304-1308.

Haug, G.H.; D. Gunther, L.C. Peterson, and D.M. Sigman

2003 Climate and the collapse of Maya civilization. Science 299: 1731-735.

Hodell, D.A.; J.H. Curtis and Brenner

1995 Possible role of climate in the collapse of Maya civilization. NATURE 375: 391-394.

Inomata, $\mathrm{T}$.

2004 The spatial mobility of non-elite populations in Classic Maya society and its political implications. In Ancient Maya Commoners (J.C. Lohse and F. Valdez editors), University of Texas, Austin, pages 175-196.

Kowalski, J.K. and N.P. Dunning

1999 The architecture of Uxmal: the symbolics of statemaking at a Puuc Maya regional capital. In Mesoamerican Architecture as a Cultural Symbol (J. Kowalski editor), Oxford University Press, New York, pages 273-297.

Lawrence, D.; P. D’ororico; L. Diekmann; M. Delong; R. Das;

J. Eaton

2007 Ecological feedbacks following deforestation create the potential for a catastrophic ecosystem shift in a tropical dry forest. Proceedings of the National Academy of Sciences USA 104: 20696-20701.

Lentz, D.L. and B. Hockaday

2009 Tikal temples and timbers: ancient Maya agroforestry and the end of time. Journal of Archaeological Science 36: 1342-1353.

Lucero, L.J.

2002 The collapse of the Classic Maya: a case for the role of water control. American Anthropologist 104: 814-826.

Luzzadder-Beach, S.; T. Beach and N.P. Dunning

2012 Wetland fields as mirrors of drought and the Maya abandonment. Proceedings of the National Academy of Science USA 109: 3646-3651

Mcanany, P.A. and Gallareta Negrón

2010 Bellicose rulers and climatological peril? Retrofitting

Twenty-first-century woes on Eighth-century Maya society. In Questioning Collapse: Human Resilience, Eological Vulnerability, and the Aftermath of Empire (P.A. McAnany and N. Yoffee editors), Cambridge University Press, New York, pages 142-175.

Marcus, J.

1993 Ancient Maya political organization. In Lowland Maya Civilization in the Eighth Century A.D. (J. Sabloff and J. Henderson editors), Dumbarton Oaks, Washington DC, pages 111-183.

Martin, S. and N. Grube

2008 Chronicles of the Maya Kings and Queens. Thames \& Hudson, New York.

Masson, M.A.

2000 In the Realm of Nachan Kan: Postclassic Maya Archaeology of the Laguna de On, Belize. University of Colorado Press, Boulder.

Medina-elizade, M.; S. Burns; D.W. Lea; Y. Asmerom;

L.Von gunten; V. Polyak; M. Vuille and A. Karmalkar

2010 High resolution stalagmite climate record from the Yucatan Peninsula spanning the Maya Terminal Classic period. Earth and Planetary Science Letters 298: 255-262.
Medina-Elizade, M. and E.J. Rohling

2012 Collapse of Classic Maya civilization related to modest reduction in precipitation. Science 335: 956-959.

Mendoza, B.; V. García-Acosta; V. Velasco; E. JÁurengui and

R. Díaz Sandoval

2006 Frequency and duration of historical droughts from the 16th to the 19th centuries in the Mexican Maya lands of the Yucatan Peninsula. Climate Change 83: 151-168.

Mueller, A.D.; G. Islebe, M.B. Hillesheim; D. Grzesik; F. Anselmetti; D. Ariztegui; M. Brenner; J. Curis; D. Hodell and K.Venz

2010 Recovery of the forest ecosystem in the tropical lowlands of northern Guatemala after the disintegraion of Classic Maya polities. Geology 38: 523-526.

Oglesby, R.J.; T.L. Sever; W. Saturno; D.J. Erickson III and

J. Sriishen

2010 Journal of Geophysical Research 115, D12106, doi: 10.1029/2009JD01 1942.

O'Mansky, M. and N.P. Dunning

2004 Settlement and Late Classic political disintegration in the Petexbatun Region, Guatemala. In The Terminal Classic in the Maya Lowlands: Collapse, Transition, and Transformation (A. Demarest, P. Rice, and D. Rice editors), University of Colorado Press, Boulder), pages 83-101.

Palka, J.W.

2003 Social Status and Differential Processes of Abandonment at the Classic Maya Center of Dos Pilas, Peten, Guatemala. In The Archaeology of Settlement Abandonment in Middle America (T. Inomata and R.W. Webb editors), University of Utah Press, Salt Lake City, pages 121-133.

Pérez-Salicrup, D.

2004 Forest types and their implications. In Integrated LandChange Science and Tropical Deforestation in the Southern Yucatan (B.L. Turner II, J. Geoghagen, and D.R. Foster editors) Oxford University Press, New York, pages 63-80.

Pohl M. and P. Bloom

1996 Prehistoric Maya farming in the wetlands of Belize: more data from Albion Island. In The Managed Mosaic. Ancient Maya Agriculture and Resource Use (S. Fedick editor) University of Utah Press, pages 145-164.

Quintana, O. and W. Wurster

2001 Ciudades Mayas del Noreste del Petén, Guatemala: Un Estudio Urbanístico Comparativo. Verlag Philipp von Zabern, Mainz am Rhein.

Reese-Taylor, K. and D. Walker

2002 The passage of the Late Preclassic into the Early Classic. In Ancient Maya Political Economies (M.A. Masson and D.A. Friedel editors), AltaMira Press, Walnut Creek, California, pages 87-122.

Rivera Dorado, M.

1996 Los Mayas de Oxkintok. Ministerio de Educación y Cultura, Madrid.

Robin, C.

2001 Peopling the past: new perspectives on the ancient Maya. Proceedings of the National Academy of Science 98: 18-21.

Rosenmeier, M.F.; D.A. Hodell; M. Brenner, J.H. Curtis and T.P. Guilderson

2002 A 4,000-year lacustrine record of environmental change in the southern Maya Lowlands, Peten, Guatemala. Quaternary Research 57: 183-190. 
Sabloff, J.A.

2007 It depends on how you look at things: new perspectives on the Postclassic period in the northern Maya lowlands. Proceedings of the American Philosophical Society 115: 11-25.

Scarborough, V.L and G. Gallopin

1991 A water storage adaptation in the Maya lowlands. Science 251: 658-662.

Scarborough, V.; N. Dunning; K. Tankersley; C. Carr; E. Weaver,

L. Grazioso; B. Lane; J.G. Jones; P. Buttles; F. Valdez and D. Lentz 2012 Water and sustainable land use at the ancient tropical city of Tikal, Guatemala. Proceedings of the National Academy of Science USA 109: 12408-12413.

Smyth, M.P.

1998 Before the florescence: chronological reconstructions at Chac II, Yucatan, Mexico. Ancient Mesoamerica 9: $137-150$.

Smyth, M.P.; D. Ortegón Zapata; N.P. Dunning and E. Weaver 2013 Settlement Dynamics, Climate Change, and Human Response at Xcoch in the Puuc Region of Yucatan, Mexico. In The Archaeology of Yucatan: New Directions and Data (T. Stanton editor) BAR International Series, Oxford, in press.

Tankersley, K.; V. Scarborough; N. Dunning; W. Huff; B. Maynard and T. Gerke

2011 Evidence for volcanic ash fall in the Maya lowlands from a reservoir at Tikal, Guatemala. Journal of Archaeological Science 38: 2925-2938.

Turner, B.L. II

2010 Unlocking the ancient Maya and their environment: paleo-evidence and dating resolution. Geology 38: 575-576.

Turner, B.L. II and P. Harrison, editors

1983 Pulltrouser Swamp: Ancient Maya Habitat, Agriculture, and Settlement in Northern Belize. University of Texas Press, Austin.
Turner, B.L. II and J.A. Sabloff

2012 Classic Period collapse of the central Maya Lowlands: insights about human-environment relationships for sustainability. Proceedings of the National Academy of Sciences 109: 13908-13914.

Valdez, F.; L. Grazioso and P.J. Buttles

2001 Orígenes y surgimiento de Río Azul, Péten. In XIV Simposio de Investigaciones Arqueológicas en Guatemala, 2000 (J.P. Laporte, A.C. Suasnavar, and B. Arroyo editors), Museo Nacional de Arqueología y Etnología, Guatemala, pp. 93-97.

Wahl, D; R. Byrne; T. Schreiner and R. Hansen 2007 Paleolimnological evidence of Late-Holocene settlement and abandonment in the Mirador Basin, Peten, Guatemala. The Holocene 17: 813-820.

Wahl, D.; R. Byrne; T. Schreiner and R. Hansen 2006 Holocene vegetation change in the nothern Peten and its implications for Maya prehistory. Quaternary Research 65: 80-389.

Webster, J.W.; G.A. Brook; L.B. Railsback; H. Cheng;

R.L. Edwards, C. Alexander, and P.P. Reeder

2007 Stalagmite evidence from Belize indicating significant droughts at the time of preclassic abandonment, the Maya hiatus, and the classic Maya collapse. Palaeogeography, Palaeoclimatology, Palaeoecology 250: 1-17.

Weiss-Krejc, E. and T. Sabbas

2002 The potential role of small depressions as water storage features in the central Maya lowlands Latin American Antiquity 13: 343-357.

Yaeger, J. and D.A. Hodell

2008 The collapse of Maya civilization: assessing the interaction of culture, climate, and environment. In El Niño: Catastrophism and Culture Change in Ancient America (D. Sandweiss and J. Quilter editors), Dumbarton Oaks, Washington DC, pages 187-242. 
